Бойко Р. В., к.т.н., с.н.с. ${ }^{1}$;

Бутенко М. П. ' ;

Гудим В. М. ${ }^{2}$

1 - Центр воєнно-стратегічних досліджень Національного університету оборони України імені Івана Черняховського, Київ;

2 - Інститут державного військового управління Національного університету оборони України імені Івана Черняховського, Київ

\title{
Формування підходів до планування спроможностей військ (сил) 3 врахуванням їх ресурсного забезпечення
}

Резюме. У статті викладено пропозиції щодо удосконалення планування спроможностей військ (сил) з врахуванням їх ресурсного забезпечення.

Ключові слова: потреба, матеріально-технічне забезпечення, фінансування, розподіл.

Постановка проблеми. Зміни характеру сучасних воєнних конфліктів, які були спрямовані на знищення можливих супротивників із напруженням усіх наявних людських і матеріальних ресурсів, поступово відходять на другий план. Актуальнішими стають нові сценарії, зміни діапазону та зміст завдань, до виконання яких залучаються Збройні Сили України (далі - ЗСУ), збільшення загроз, задекларований Президентом України, поступовий перехід українського війська на професійну основу до кінця 2020 року, складні економічні та військово-технічні умови розвитку ЗСУ та низькі показники ефективності виконання програм їх розвитку. Це вимагає формування нових підходів до планування спроможностей військ (сил) 3 врахуванням їх рівня забезпеченості, адже останнім часом у світі спостерігається стійка тенденція до зростання матеріально-технічних потреб військ як у мирний, так і у воєнний час [1-3].

На сьогодні на сході України, коли ЗСУ змушені стримувати наступ агресора та незважаючи на турботу усього суспільства про забезпечення бійців антитерористичної операції (АТО), потреби ЗСУ у фінансових та матеріально-технічних pecypcax задовольняються не повною мірою. У військах бракує як зброї і боєприпасів, так і провіанту та одягу. Зрозуміло, що у цій справі існують два найважливіших чинники - час і якість підготовки достатньої кількості війська до рівня спроможності протистояти військам агресора. При цьому не слід забувати, що нинішньому вищому військово-політичному керівництву доводиться розв'язувати двоєдине завдання - готувати частини та підрозділи безпосередньо для зони проведення АТО й одночасно турбуватися про створення принаймні оперативного боєздатного резерву. Не кажучи вже про необхідність підтримувати його у високому ступені готовності на випадок, якщо агресор перейде від гібридної форми агресії до прямого широкомасштабного озброєного вторгнення. У такій ситуації повномасштабне, інтенсивне і максимально повне використання існуючої навчально-матеріальної бази, а також іiі трансформація до кращих світових стандартів, які дали змогу б підняти якість підготовки українського війська на значно вищий рівень, одне 3 ключових питань. Отже, пошук науково обгрунтованих шляхів планування на основі спроможностей (ПОС) військ (сил) 3 врахуванням їх рівня забезпеченості $\epsilon$ актуальним науковим і практичним завданням.

Теоретичні засади оборонного планування на основі спроможностей були розроблені корпорацією RAND у 1950-х роках та практично впроваджені Міністром оборони США Робертом Макнамарою в 1962 році. У подальшому система була істотно допрацьована та нині використовується в оборонному плануванні провідних країн світу. Водночас, питанням матеріально-технічного забезпечення військ на засадах логістики присвячені наукові дослідження зарубіжних та українських науковців: М. Кристофера, Д. Ламберта, Дж. Коула, В. Ніколайчука, А. Сухорукова, Л. Фролова, Н. Чухрай та інших. Однак питання вдосконалення планування спроможностей військ (сил) 3 врахуванням їх ресурсного забезпечення та підвищення на цій основі рівня безпеки держави комплексно не висвітлюються в науковій літературі. 
Метою статті є визначення можливого підходу до планування спроможностей військ (сил) 3 врахуванням їх ресурсного забезпечення.

\section{Виклад основного матеріалу.}

Історичний досвід свідчить, що рівень обороноздатності держави залежить від воєнно-економічного потенціалу країни. Захист держави неможливий без раціонального матеріально-технічного забезпечення збройних сил. На думку воєнних спеціалістів США, “один тил не може виграти війну, але один тил може програти війну" [1]. Показово, що бойовий склад армії США становить майже $30 \%$, а $60 \%$ особового складу припадає на служби забезпечення [2].

Сучасні локальні війни і збройні конфлікти вимагають величезних матеріальних і фінансових витрат, великих людських ресурсів, проведення спеціальної ресурсної підготовки, без якої неможливе задоволення їхніх потреб. Сучасні підходи щодо планування спроможностей військ (сил) 3 врахуванням їx ресурсного забезпечення, повинні оперативно отримувати інформацію 3 автоматизованої системи логістики, інфраструктури та відповідати стандартам класифікації та управління матеріальнотехнічними засобами, які прийняті та впроваджені в НАТО.

Ідея впровадження методу планування на основі спроможностей, полягала в тому, щоб військові організації не знали яка країна, об'єднання країн або недержавні військові формування можуть потенційно представляти майбутню загрозу безпеці. А це означає, як стверджують деякі аналітики, що ПОС замінило систему планування на основі загроз, які використовувалась під час холодної війни. Проте насправді ПОС замінило планування на основі сценаріїв, яке використовувалось протягом 1990-х років (Ірак та Північна Кореї, що кваліфікувались як основні місця регіональних конфліктів, а пізніше, як основні театри військових дій). Отже, щоб подолати проблему невизначеного ворога, було запропоновано ідею, що США може передбачити спроможності, які противник буде застосовувати. У зв' язку з цим, модель на основі спроможностей дасть змогу країні зосередитися на тому, як “противник може воювати, а не хто може бути противником, або де може статися війна". Остаточне впровадження в систему оборонного планування методу планування на основі спроможностей у військових установах США відбулося у 2004 році після оприлюднення
Підсумкового звіту щодо досліджень об'єднаних оборонних спроможностей. У цьому Звіті зазначалося, що види збройних сил (сухопутні війська, військово-морські сили, повітряні сили та морська піхота) домінували в існуючому процесі планування на основі потреб та, як правило, не розглядали повний спектр рішень для задоволення потреб міжвидового ведення збройної боротьби. У Звіті рекомендувалося застосувати процес ПОС для забезпечення домінування об'єднаних потреб у процесі планування, а також для надання вищим керівникам Міністерства оборони можливості впливу на початку процесу планування, а не на його кінцевих етапах, коли це вже $\epsilon$ неефективним.

Процес планування на основі спроможностей не має універсального визначення, але більшість практиків погодяться 3 наступним: "ПОС - це планування в умовах невизначеності для забезпечення відповідних спроможностей, які підходять для широкого спектра сучасних умов та викликів, в межах економічних можливостей держави". ПОС - це системний підхід, спрямований на виявлення та надання рекомендацій щодо найбільш прийнятних за критерієм “вартість-ефективність" варіантів розвитку військ (сил) для задоволення пріоритетів національної безпеки.

Особливості застосування планування 3 використанням методу ПОС у рамках процесу розвитку власних збройних сил, згідно зі стандартами НАТО, полягають у тому, що $[5,6]:$ ПОС є процесом, який застосовується у процесі розвитку збройних сил; ПОС використовується для формування майбутніх спроможностей збройних сил; ПОС - це комплексний, послідовний, логічний процес визначення типів спроможностей, які необхідні військам (силам) мати у майбутньому; ПОС не може прогнозувати все, отже для процесу розвитку збройних сил все ще потрібно буде передбачити здатність швидко реагувати на непередбачені обставини (здійснювати обгрунтоване коригування планів досягнення визначених кінцевих цілей розвитку збройних сил).

Використання методу планування на основі спроможностей у процесі розвитку ЗС України дасть змогу отримати компроміс між рівнем загроз та можливими витратами державного бюджету. Сутність ПОС наведено на рис. 1. Іншими словами, ПОС - процес, який підтримується державною системою планування в рамках формування програм та бюджету. Його слід адаптувати до обставин 
окремих країн - шаблон може виглядати однаково, але застосовуватиметься порізному, не має стандартного алгоритму для всіх. Яскравим прикладом цього є сучасні особливості впровадження 3 наступного року методу "планування на основі спроможностей” в ЗС України. Сам метод передбачає, що планування на основі спроможностей не базується на конкретному противнику (що було притаманно оборонному плануванню США під час холодної війни), а також не грунтується на конкретному сценарії імовірного конфлікту (планування на основі сценаріїв, яке було притаманним оборонному плануванню США відразу після закінчення холодної війни). Тобто під час планування на основі спроможностей передбачається, що планування буде здійснюватися на основі переліку загальних потенційних загроз без прив' язування до конкретного противника або сценарію. 3 іншого боку, треба зрозуміти, що ПОС не є плануванням на основі ресурсів, тобто плануванням від бюджету. ПОС повинно враховувати ресурси 3 метою вибору оптимального переліку спроможностей, доступних у рамках встановленого бюджету.

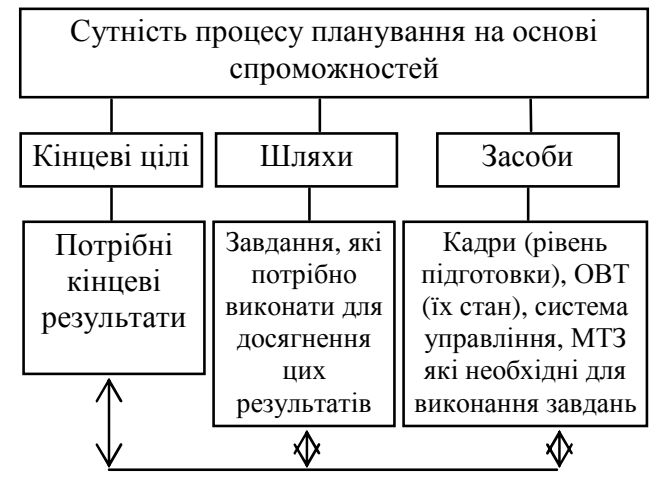

Рис. 1.

Зміст процесу планування розвитку 3С України на основі спроможностей складається 3 декілька взаємопов'язаних між собою кроків: аналізу стратегічних вказівок $\mathrm{i}$ політичної стратегії держави; відпрацювання варіанта обстановки (сценаріїв застосування збройних сил); визначення завдань військам (силам) відповідно до можливих сценаріїв застосування; визначення вимог до спроможностей військ (сил) на визначений період; визначення нестач спроможностей; пошуку та обгрунтування рішень щодо оптимального розподілу ресурсів.

Особливим у процесі планування на основі спроможностей $\epsilon$ процес їх матеріально-технічного забезпечення (рис. 2).

Матеріально-технічне забезпечення збройних сил - це комплекс заходів військового управління і спеціальних служб всіх видах операцій (бойових дій) та повсякденної життєдіяльності збройних сил, що здійснюються $з$ метою забезпечення військ (сил) військовою технікою, боєприпасами, військово-технічним майном, підвищення ефективності та експлуатаційної надійності військової техніки, швидкого ii відновлення (ремонту) після ушкоджень, задоволення матеріальних, транспортних, побутових та інших потреб військ (сил) для підтримання їх у бойовій готовності до виконання покладених на них бойових чи повсякденних завдань [4-7].

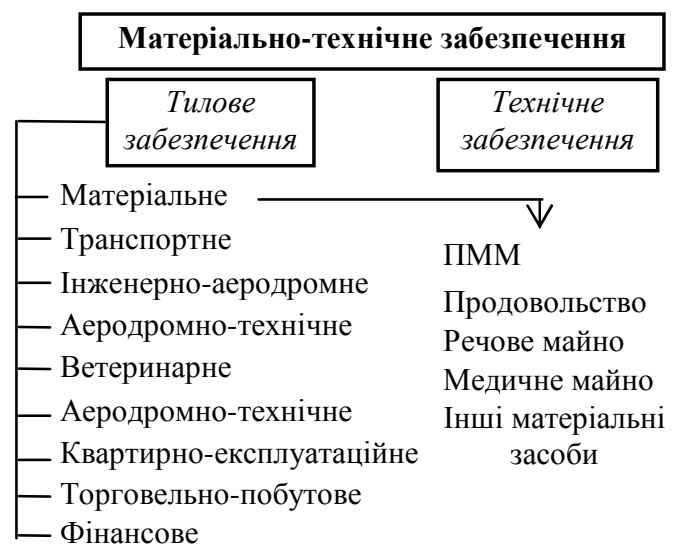

Рис. 2. Складові МТ3

Матеріально-технічне забезпечення повинно організовуватись і здійснюватись для своєчасного і повного забезпечення підрозділів необхідною кількістю паливно-мастильних матеріалів (ПММ), продовольства, речового, медичного майна та інших матеріальнотехнічних засобів і включати накопичення їх до встановлених норм, збереження, своєчасну підготовку до використання за призначенням та поповнення за необхідністю.

Стандарти забезпечення Збройних Сил України застаріли i потребують оновлення. Армія не має змоги ефективно управляти своїм майном, вести облік та контролювати його рух. Практично всі процеси знаходяться в ручному управлінні, автоматизація мінімальна.

Автоматизацію процесу планування на основі спроможностей 3 врахуванням ресурсного забезпечення у спрощеному вигляді опишемо так: розпочнемо 3 того, що потрібно досягти та будемо рухатися у зворотному напрямі до того, що необхідно набути. Це буде підкреслювати результати (що досягнуто) у порівнянні з діями (що зроблено). Визначення обсягів спроможностей, яких не вистачає для виконання амбіційних завдань $\Delta S, \epsilon$ різницею між потрібними $S_{\text {п }}$ та наявними спроможностями збройних сил та інших військових формувань $S_{\mathrm{H}}$ :

$$
\Delta S=S_{\text {п }}-S_{\text {н }}, \Delta S=0 \text { при } S_{\text {п }} \geq S_{\text {н }} .
$$


Оцінювання та наступне планування може проводиться за кожною складовою усього переліку спроможностей відповідно до кожної ситуації (за необхідності), кожного сценарію та за збройними силами в цілому. Аналогічно будемо здійснювати оцінювання потрібних ресурсів для досягнення необхідних спроможностей. Для проведення відповідного оцінювання спеціалістами будуть використовуватись отримані раніше дані щодо потреб у силах i засобах збройних сил та інших військових формувань. Далі будемо використовувати ітераційний принцип чи, як кажуть, принцип “матрьошки”, тобто буде складатися база даних відповідних розрахунків у вигляді таблиць - для кожної складової спроможності та ресурсів окремо. Але форма таблиці та порядок іï заповнення будуть залишатися незмінними.

Одним 3 найвагоміших показників під час здійснення довгострокового планування можна вважати показник здатності країни $Z(T)$ створити та забезпечити власні збройні сили так, щоб вони протягом планового періоду $T$, або на його кінець (залежно від змісту плану) були спроможні виконувати як можна більше амбіційних завдань із визначеним рівнем готовності до їх виконання $W_{\mathrm{n}}(\mathrm{n}=1, \ldots, \mathrm{R}-$ кількість амбіційних завдань збройних сил протягом періоду планування $T$ ). $W_{\mathrm{n}} \in$ функцією від показника ймовірності виникнення загрози $P_{\mathrm{n}}(T)$ за визначеним завданням та сценарієм протягом планового періоду та від показника ступеня потенційної небезпеки - важкості наслідків від практичного виникнення небезпеки $L_{\mathrm{n}}(T)$, тобто:

$$
W_{\mathrm{n}}(T)=f\left[P_{n}(T) ; L_{n}(T)\right] .
$$

$\mathrm{y}$ загальному вигляді показник здатності країни $Z(T)$ щодо забезпечення необхідних спроможностей для виконання амбіційних завдань відбиває у собі показник рівня обороноздатності країни.

Планування можливих шляхів досягнення кінцевого результату, оцінювання показників можливого впливу вирішується ітераційно, як у прямій постановці, так і у зворотному напрямі. Тобто здійснюється пошук та вибір раціонального рішення у процесах планування від амбіцій та планування на основі спроможностей (іноді кажуть планування від ресурсів). Розроблення планів та програм, аналіз їх реалізуємості має важливе практичне значення. Вплив ресурсного забезпечення на вибір напрямів розвитку збройних сил буде лімітувати кількість амбіційних завдань, що покладатимуться на збройні сили та навпаки, при їх зростанні в обсягах чи досягнення найбільшої раціональності в діях додавати найактуальніші завдання до переліку завдань, які можна виконати. Шляхи вирішення будьякого завдання розвитку також залежатимуть від можливих впливів економічних чинників та будуть відбиватися на кінцевому результаті. Адже великою проблемою логістики не лише збройних сил, а й взагалі сил оборони $є$ те, що під час операції, до неї залучаються, як правило, всі силові відомства. При цьому відсутня система взаєморозрахунків, взаємообміну матеріальними засобами тощо. Така ситуація виникає через те, що забезпечення ведеться за умов мирного часу. Кожна складова сил оборони отримує по своїй лінії тільки те, що замовляє без урахування сумісних підрозділів. Під час проведення спільних операцій сил оборони логістика виходить на інший рівень. В операції можуть брати участь представники силових структур, кожна 3 яких має окремий бюджет. Це не просто асигнування, які витрачаються на утримання, грошове забезпечення тощо, а кошти саме на проведення операції. Тому певною проблемою $є$ проведення взаєморозрахунків.

Армії провідних європейських країн займаються підготовкою, як i належить, у пунктах постійної дислокації чи на базах. Відповідно до цих потреб організована i логістика. Коли ж йдеться про ухвалення рішення щодо застосування підрозділів, починає працювати інша система забезпечення. Наприклад, створюється об'єднане оперативне командування, якому підпорядковуються частини 3 різних видів та родів військ. Цей орган планує операцію та іiі логістичне забезпечення. Наприклад, бюджет операції "Буря в пустелі" становив 3 млрд доларів. Кошти на їі проведення виділялися окремо, а не 3 рахунків утримання частин, які брали в ній участь.

У Збройних Силах України поки що немає розділення понять "підготовка" i “застосування” сил. Для того, аби цей принцип запрацював, як у країнах НАТО, необхідно змінити всю систему логістики до батальйону i роти включно, адже органи управління в теперішньому вигляді не здатні працювати в умовах чіткого розподілу. Наприклад, аби 3'ясувати загальний стан справ 3 ресурсного забезпечення, командир має звернутися до штабу Тилу, Озброєння, Управління оперативного забезпечення та багатьох різних 
структур. Адже загальної організації, де б оперативно збирали та аналізували всю інформацію, у Збройних Силах поки немає. Кожен посадовець ніби й відповідає за свою ділянку роботи, але “загальної картини” ніхто відтворити не може. Тим часом для ухвалення рішення будь-якому командирові потрібні саме узагальнені дані. Саме тому у Стратегічному оборонному бюлетені (Указ Президента України від 06.06.2016), викладено необхідність створення Головного управління логістики i Командування Сил логістики. Перша структура — це J-4 за натовськими стандартами. Вона необхідна для того, щоб командувач міг вирішити необхідні питання в одному місці. Саме в J-4 він зможе отримати всю необхідну інформацію.

Для повного розуміння вимог до спроможностей та визначення недостатніх спроможностей, необхідно постійно перевіряти відповідність наявної організаційної структури військ (сил) визначеним сценаріям їх можливого застосування. Сценарії можуть і повинні бути розроблені на підставі існуючих планів проведення операцій та планів дій в надзвичайних ситуаціях, але вони не повинні обмежуватися цим. Як правило, вони повинні виходити за рамки найбільш вірогідної ситуації застосування, та хоча б включати в себе менш вірогідні, але можливі (і можливо більш ризиковані) ситуації застосування 3С України. Сценарії, які не дають можливості ретельно перевірити відповідність організаційної структури військ (сил) можливим викликам, не можуть визначити де існують слабкі місця та проблеми, а отже, можуть сприяти створенню такої організаційної структури військ (сил), яка по суті не придатна для застосування у широкому спектрі ситуацій.

$$
Z=f\left(W_{\text {БГзСі }}\right)=f\left(U_{i} ; T_{i}\right) \Rightarrow\left\{U_{i}=\frac{U_{\text {реал. }}}{U_{\text {необ. }}} \quad T_{i}=\frac{T_{\text {реал. }}}{T_{\text {необ. }}},\right.
$$

де $U_{\text {ревал. }} U_{\text {необ }}$ - реальні (забезпечені) показники якості виконання поставлених завдань (можуть бути різними військовими та невійськовими, наприклад: рівень можливих втрат своїх або противника; кількість підготовлених підрозділів та якість їх підготовки, якість забезпечення зв'язком; кількість міжнародних заходів та навчань тощо):

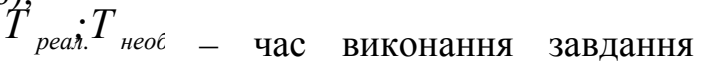

реальний (забезпечений) та необхідний (розрахунковий).
Сценарії та ситуації будуть використовуватися для розпізнавання та визначення тих спроможностей, які будуть потрібні для застосування у майбутніх конфліктах. Проте спочатку спроможності військ (сил) повинні бути класифіковані за групами. Класифікація спроможностей дає змогу розкласти їх на більш прості частини. Це необхідно через масштабність проблем, що досліджуються, бо легше працювати 3 нижчим рівнем деталізації, тобто розділивши спроможності на менші групи. Ретельний вибір розподілу спроможностей на групи також може скоротити кількість випадків, коли ОВТ або особовий склад залучається за декількома групами.

Під час визначення складових спроможностей ЗС України, яких не вистачає для виконання амбіційних завдань, першим кроком $\epsilon$ обмеження переліку амбіційних завдань 3 урахуванням вимог чинного законодавства, а також за показниками прогнозних економічних можливостей держави щодо можливості забезпечення ЗС України взагалі. Визначення цих показників потребує однозначного встановлення за яким показником визначатимуться заплановані (прогнозні) витрати на ЗС України. Визначеність 3 показником фінансування збройних сил надасть можливість встановити обсяги завдань, що будуть покладатися на них у плановий період, та сформувати більш адекватний перелік необхідних спроможностей ЗС України. Спроможності ЗС України щодо виконання покладених на них завдань можуть характеризуватися відносними показниками готовності визначеного складу військ (сил) виконувати поставлені завдання та відносними часовими і якісними показниками можливого виконання цього завдання:

Кінцевий результат планування будьякий визначений період на попередньому етапі оцінювання буде знаходиться в постійному динамічному русі, але змінюватиметься у визначених межах.

Така система показників буде характеризувати перелік завдань та сценаріїв, які держава спроможна забезпечити за попереднім оцінюванням 3 урахуванням обмежень, які накладаються чинним законодавством та економічними можливостями держави. Попереднє оцінювання показників (4) дасть змогу сформувати перелік 
необхідних спроможностей ЗС України, яких вони повинні набути протягом планового періоду для виконання визначеного переліку завдань. Це можна вважати відправною

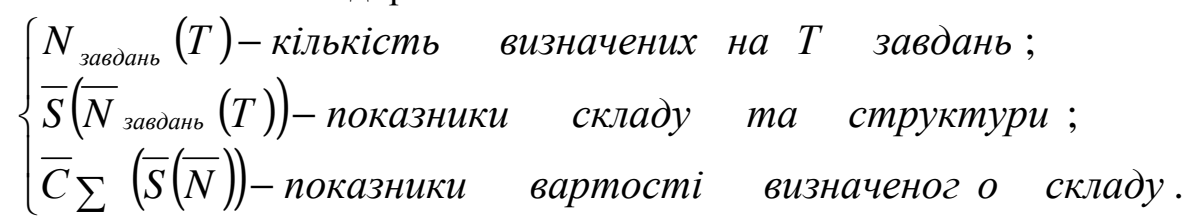

Перспективне планування не повинно ставити себе в повну залежність від наявності ресурсів. Об'єктивні потреби у виконанні постійно зростаючої кількості та обсягу завдань можуть бути стимулюючим фактором для пошуку нових шляхів розвитку збройних сил, нових технологій, нових матеріальних ресурсів тощо. Тобто в процесі планування необхідно враховувати ті ресурсні можливості, яких держава протягом планового періоду може досягти. Водночас, діапазон

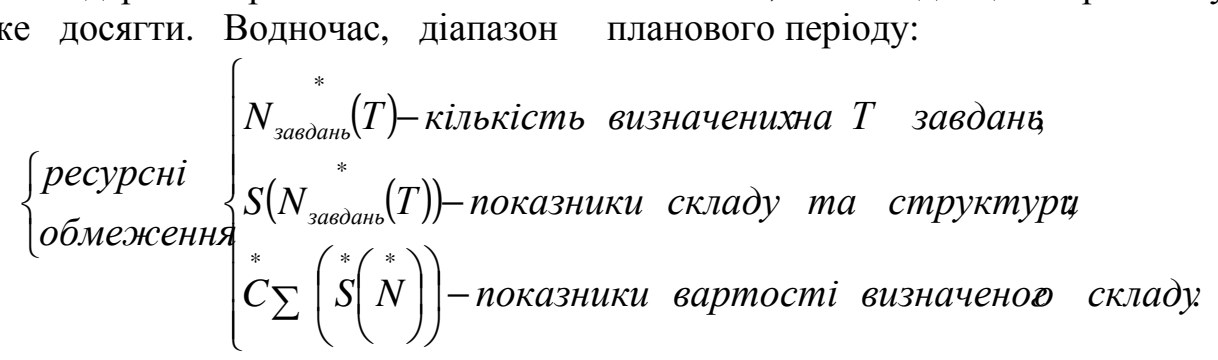

Ці показники розкривають межі можливої реалізуємості програм і планів та $\epsilon$ показниками, яких необхідно досягти протягом визначеного планового періоду. На цьому етапі визначаються показники цільової ефективності вирішення $i$-го завдання за $j$-м сценарієм $(\boldsymbol{W} i j)$ та показники сумарної вартості усіх видів ресурсів, необхідних для виконання поставлених завдань на визначеному рівні $\boldsymbol{C}_{\Sigma i}$.

Застосуванням методів аналізу та перебору різних варіантів показників складу та структури військ (сил) визначаються варіанти, які найбільш економічно ефективні та обгрунтовані за показником, який характеризує кількість отриманого ефекту на одиницю запланованих або витрачених ресурсів:

$$
E_{i j}=W_{i j} / C_{\sum_{i j}}
$$

де $E_{i j}$ - ефективність підготовки ЗС України до вирішення $i$-го завдання за $j$-м сценарієм, визначеним складом військ (сил).

Показник $W_{i j}$ характеризує необхідні показники готовності військ (сил) до виконання обмеженого переліку завдань, які вони повинні досягти протягом планового періоду. У подальшому процес оцінювання спроможностей ЗС України щодо виконання спроможностей 3С України на плановий період повинен бути чітко визначений та відповідати ресурсним можливостям держави.

Наступним кроком процесу оцінювання складових спроможностей, яких не вистачає для виконання збройними силами вже визначеного переліку амбіційних завдань, $\epsilon$ визначення аналогічної системи показників (5), але за умов урахування ресурсних та інших обмежень, $з$ їх тенденціями розвитку протягом

амбіційних завдань зводиться до балансування між економічними показники забезпечення цих спроможностей (планові та реальні за роками показники фінансування ЗС України) та показниками вартості створення необхідних спроможностей 3С України.

Висновок та напрям подальших досліджень. Проведені в статті дослідження дають змогу зрозуміти основні особливості планування розвитку збройних сил на основі спроможностей 3 врахуванням їх ресурсного забезпечення. Наступним етапом розвитку системи оборонного планування в найближчій перспективі $\epsilon$ перехід до планування на основі спроможностей 3 врахуванням їх ресурсного забезпечення, які дадуть змогу виконувати завдання в динаміці. Набуття визначених спроможностей та їх ресурсне забезпечення дасть змогу враховувати усі потенціальні сценарії розвитку обстановки та визначати завдання щодо оборони держави, захисту суверенітету та територіальної цілісності. Стратегічна мета щодо набуття ЗС України визначених спроможностей торкається питань підвищення ефективності підготовки військ (сил), інтеграції в цей процес стандартів НАТО, врахування досвіду антитерористичної операції. 


\section{СПИСОК ВИКОРИСТАНОЇ ЛІТЕРАТУРИ}

1. Пріоритети розвитку Збройних Сил України 3 урахуванням участі у гібридній війні 20152016 / [Електронний ресурс]. - Режим доступу: http//www.president.gov.ua/documents.

2. Україна 2014-2015: Долаючи виклики (аналітичні оцінки) / [Електронний ресурс]. Режим http//www.razumkov.org.ua/upload/ доступу: Pidsumky_2014_2016_A4_fnl.pdf.

3. Російська збройна агресія проти України (20142016) / [Електронний ресурс] - Режим доступу: http//uk.wikipedia.org/.

4. Дорожная карта внедрения системы оборонного планирования на основе возможностей в ВСУ. Выступление МО Украины 26.01.17 / [Электронный ресурс] - Режим доступу: http://ru.golos.ua/suspilstvo/poltorak_ utverdil_dorojnuyu_kartu_po_vnedreniyu_sistemyi_o boronnogo_planirovaniya_08.

5. Масловский С. С. Оборонное планирование на основе возможностей с учётом долгосрочной Российской угрозы. 16.05.2017 / [Электронный ресурс ] - Режим доступу: https://censor.net.ua/news/440093/oboronnoe_ planir ovanie_ukrainy_uchityvaet_dolgosrochnuyu_rossiyisk uyu_ugrozu_genshtab.

6. Т. Тагарєв., Основні питання програмноорієнтовного управління оборонними ресурсами // Наука і оборона - К.: 2006. - № 3. - С. 18-24.

7. Онофрійчук П. В. Нові підходи до обгрунтування рішень у сфері ресурсного та організаційного забезпечення збройних сил / П. В. Онофрійчук // Проблеми науки [Текст]. - 2008. - №4. - С. 20-26.

Стаття надійшла до редакції 08.11.2017

Бойко Р. В., к.т.н., с.н.с. ${ }^{1}$;

Бутенко Н. Ф. ${ }^{\text {; }}$;

Гудым В. Н. ${ }^{2}$

${ }_{1}$ - Центр военно-стратегических исследований Национального университета обороны Украины имени Ивана Черняховского, Киев;

${ }^{2}$ - Институт государственного военного управления Национального университета обороны Украины имени Ивана Черняховского, Киев

Формирование подходов к планированию возможностей войск (сил) с учетом их ресурсного обеспечения

Резюме. В статье изложены предложения по совершенствованию планирования возможностей войск (сил) с учетом их ресурсного обеспечения.

Ключевые слова: потребность, материально-техническое обеспечение, финансирование, распределение.

\section{R. Boiko, Ph.D, senior researcher ${ }^{1}$;}

N. Butenko ${ }^{1}$;

V. Goodym ${ }^{2}$

${ }^{1}$ - Center for Military and Strategic Studies of the National Defence University of Ukraine named after Ivan Cherniakhovsky, Kyiv;

2 - Institute of State Military Management of the National Defence University of Ukraine named after Ivan Cherniakhovsky, Kyiv

Formation of approaches to planning the capabilities of troops (forces), taking into account their resource provision

Resume. The article contains proposals for improving the planning of the capabilities of troops (forces), taking into account their resource support.

Keywords: need, logistics, financing, distribution. 